\title{
METHOD FOR RAPID ASSESSMENT OF ALUMINUM TOLERANCE OF PEA (Pisum sativum L.)
}

\section{M.A. VISHNYAKOVA ${ }^{1}$, E.V. SEMENOVA ${ }^{1}$, I.A. KOSAREVA ${ }^{1}$, N.D. KRAVCHUK ${ }^{1}$, S.I. LOSKUTOV ${ }^{2}$, I.V. PUKHALSKII ${ }^{2}$, A.I. SHAPOSHNIKOV ${ }^{2}$, A.L. SAZANOVA ${ }^{2}$, A.A. BELIMOV2}

${ }^{1}$ N.I. Vavilov Research Institute of Plant Industry, Federal Agency of Scientific Organizations, 42-44, ul. Bol'shaya Morskaya, St. Petersburg, 190000 Russia;

2All-Russian Research Institute for Agricultural Microbiology, Federal Agency of Scientific Organizations, 3, sh. Podbel'skogo, St. Petersburg, 196608 Russia, e-mail belimov@rambler.ru

Acknowledgements:

Supported by Russian Science Foundation (project № 14-16-00137)

Received March 10, 2015

\section{Abstract}

Crops vary considerably in their resistance to acidic soils, and many legumes, including pea (Pisum sativum L.), considered to be sensitive or moderately sensitive crops compared to cereals. The main factor determining the phytotoxicity of acidic soils is the increased concentration of mobile aluminum ions in the soil solution. Accumulation of aluminum in root tissues interferes with cell division, initiation of growth of lateral roots and uptake of minerals and water by plants. Under laboratory conditions the resistance of plants to aluminum is estimated by the degree of damage to the roots by aluminum using dyes (hematoxylin, eriochrome cyanine $\mathrm{R}$ ) and the ability of roots to restore growth after toxic effect of this metal. This work dedicated to the development of rapid assessment of aluminum tolerance especially for peas, which is as follows: the seeds were germinated in the growth chamber in the nutrient solution for 3 days $\left(7000 \mathrm{~lx}\right.$ illumination, temperature of $19^{\circ} \mathrm{C}$ at night and $21{ }^{\circ} \mathrm{C}$ during the day, photoperiod $16 \mathrm{~h}$ ), treated with a toxic concentration of aluminum chloride $(3 \mathrm{mg} \mathrm{Al} / \mathrm{l})$ for 24 hours, incubated in fresh nutrient solution without aluminum for 2 days and stained with $0.1 \%$ eriochrome cyanine $\mathrm{R}$ for $10 \mathrm{~min}$. Zone of root tissue damage by aluminum painted in the color purple. Plant resistance to aluminum was determined by the length of the root re-growth area after exposure to the toxicant. Using 19 varieties of pea from the N.I. Vavilov Research Institute of Plant Industry collection (VIR collection) it was shown that pea has high variability in tolerance to aluminum. Varieties with a minimum $(1.0 \div 1.5 \mathrm{~mm})$ length of the root re-growth (k-2759, k-3654 and k-3283) were characterized by intense purple color of the root, but varieties with a maximum $(14.0 \div 14.5 \mathrm{~mm})$ length of the root re-growth $(\mathrm{k}-4376, \mathrm{k}-9504$ and $\mathrm{k}-7307)$ had a faint but detectable staining. The proposed method makes it possible to identify genotypes contrasting in aluminum tolerance, is highly reproducible and can be used for screening and study of intraspecific variability in this trait of pea plants at very early developing stage. cyanine R.

Keywords: aluminum, hematoxylin, peas, soil acidification, acid tolerance, eriochrome

Garden pea (Pisum sativum L.) is the main legume in the Russian Federation, and the area of its production made up about 1 million hectares last years. The vast area of production involves a variety of soil and climatic conditions where unfavorable environmental factors are present, including high soil acidification. According to the Ministry of Agriculture of the Russian Federation data as of January 1, 2011, acidic soils make up 30.2 million ha or $35.6 \%$ of the examined 84.6 million hectares of tillage [1]. Crops vary considerably in their resistance to acidic soils, and many legumes (garden pea, lentils, and nut) are considered to be sensitive or moderately sensitive crops compared to cereals (rye, oats, triticale, rice, wheat, and barley) and corn [2-5]. Despite its sensitivity to toxic aluminum ions, pea plants, in some degree, can be resistant to soil acidity $[3,6]$.

It is known that the main factor determining the phytotoxicity of acidic 
soils is the increased concentration of mobile aluminum ions in the soil solution [6-8]. Toxic concentrations of aluminum ions vary greatly for different plants species which largely determines their resistance to acidic soils [9]. As a result of aluminum ions toxic effect, damage and termination of cell division and elongation of root tip cells occur [10-12]. Plant roots sensitivity to aluminum is correlated with the intensity of its penetration into cells positively and with the intensity of its withdrawal from the cells negatively [13]. Aluminum accumulation in the cell membrane and root symplast affects adversely a number of processes that determine plant growth. In particular, cell division [14], membrane pectin fermentation [15], and the synthesis of actin for root cell cytoskeleton formation are damaged [16]. Further, inhibition of the initiation and growth of lateral roots and root hairs and a breach of plant supply with minerals and water take place $[12,17]$.

The problem of acidic soils is solved based on two approaches, i.e., through soil liming (an expensive and not always effective method) and by creation of acid resistant plant varieties, helped by a significant intra-specific variation of the aluminum tolerability in crops and relatively simple schemes for screening and selection $[5,18]$. The most frequently used laboratory methods for gene pool aluminum tolerability screening are based on various modifications of seed germination in aqueous culture in the presence of aluminum toxic concentrations. These methods are simple to implement, do not require much time, have high capacity and make the diagnosis of genotype and individual plants possible in the early stages of ontogeny. This gives them advantages over the growing and field methods where a strong variability in $\mathrm{pH}$ and in aluminum content in the soil solution, and the influence of other uncontrollable factors are possible.

In laboratory tests, plant resistance to aluminum is estimated using the hematoxylin [19-20] and eriochrome cyanine R [21] dyes from the extent of damage to the roots of seedlings by aluminum. Hematoxylin forms black-blue colored complexes with aluminum. The color intensity depends on the aluminum content in plant tissues. Plants sensitive to aluminum cannot effectively eliminate it from cells and accumulate the toxicant in the symplast and cell membranes where it binds the dye. In stable samples, aluminum ions are either eliminated from tissues actively or bound in complexes that do not react with the dye, and probably do not have biological activity [20]. This approach has been successfully applied to assess the intra-specific aluminum tolerability variation in soybean [4], corn [4, 19], wheat [21], and sorghum [4, 22]. However, this method has been mentioned $[5,23,24]$ to have significant disadvantages which include subjective assessment of resistance using a point system; uneven hematoxylin washout from roots; in each experiment, the need to include genotypes that are the standards of root coloration; no staining in most aluminum tolerable genotypes.

Eriochrome cyanine $\mathrm{R}$ forms a purple colored complex with aluminum and is used to detect and determine aluminum concentrations in chemistry [25], chromatography [26], medicine [27], cytology [28], and ecology [29]. To study the effect of aluminum on plants, including assessment of intra-specific plant aluminum tolerability, this dye was first used in the comparison of aluminum content in different wheat varieties [21] and then in rye and triticale [2]. The results of our previous studies have shown that eriochrome cyanine R can be successfully used in intra-specific aluminum tolerability screening in other cereal crops, namely in goat grass [30], triticale [31], oats [31] and corn [32]. Therefore, it seems appropriate to use eriochrome cyanine $\mathrm{R}$ to study intra-specific variation of resistance to aluminum in peas.

The average yield of peas in the Russian Federation is relatively low and 
amounts to $14-18 \mathrm{t} / \mathrm{ha}[33,34]$. Since the most of pea crops are in the territory occupied by acidic soils, aluminum toxicity certainly makes a negative contribution to the reduction of pea productivity. Therefore, modern varieties, along with the features of high yield, resistance to pathogens, processability, etc., should be given aluminum tolerability [35]. The first step in these studies should be the search for the form resistant to aluminum in acid environment within the pea gene pool.

Our purpose was to develop a method of rapid assessment of aluminum tolerance in collection samples of peas using the eriochrome cyanine $\mathrm{R}$ dye.

Technique. The study included 19 specimens of pea (Pisum sativum L.) from the collection of Plant Genetic Resources of the N.I. Vavilov Research Institute of Plant Industry (VIR). Experiments were performed in a climate chamber with illumination of 7,000 lux, temperature of $19{ }^{\circ} \mathrm{C}$ (night) and $21^{\circ} \mathrm{C}$ (daytime) and a 16-hour photoperiod. Seeds (25 pcs of each sample) were laid out in special cuvettes with cells and mesh bottom, cuvettes were placed in 6-liter containers on the surface of nutrient solution and covered with transparent plastic film. Nutrient solution contained $\mathrm{CaCl}_{2} 0.4 \mathrm{mM}$; $\mathrm{KNO}_{3} 0.65 \mathrm{mM} ; \mathrm{MgCl}_{2} 0.25 \mathrm{mM} ;\left(\mathrm{NH}_{4}\right)_{2} \mathrm{SO}_{4} 0.01 \mathrm{mM} ; \mathrm{NH}_{4} \mathrm{NO}_{3} .04 \mathrm{mM}$; $\mathrm{pH} 4.2$ [2]. After 3-day germination, unfruitful seeds were discarded and the sprouts were washed with running water. Then, cuvettes with sprouts were placed in fresh nutrient solution with 6-aqueous aluminum chloride $\left(\mathrm{AlCl}_{3} \cdot 6 \mathrm{H}_{2} \mathrm{O}\right)$ added and incubated for 24 hours. Based on preliminary experiments with peas and the descriptions of legume aluminum resistance from special literature [23, 24], we used the concentrations of 2,3 and $5 \mathrm{mg} \mathrm{Al} / 1$ that had a toxic effect on plants and significantly inhibited root growth under the conditions used. Thereafter, cuvettes were placed in fresh nutrient solution without aluminum and incubated for 48 hours. Within the specified period, repair processes took place in roots (restoration of cell mitotic activity) and the roots re-grew. Sprouts were washed with running water and the roots were stained by dipping cuvettes into $0.2 \%$ hematoxylin solution for $15 \mathrm{~min}$ [2] or $0.1 \%$ eriochrome cyanine $\mathrm{R}$ solution for $10 \mathrm{~min}$ [5]. The excessive dye was washed out with running water, and the roots were dried with filter paper. The root tissue zone damaged with aluminum was stained black-and-blue by hematoxylin or purple by eriochrome cyanine R. Plant resistance to aluminum was determined by the root tip re-growth length. Two independent experiments were performed for each sample.

Statistical processing was performed by analysis of variance using the STATISTICA v. 7.0 (StatSoft Inc., USA).

Results. The studied samples differed in origin and intended use (see Table).

Garden pea samples (Pisum sativum L.) studied (collection of Plant Genetic Resources, N.I. Vavilov Institute - VIR collection)

\begin{tabular}{l|l|ll}
\hline VIR reference number & & & \multicolumn{1}{c}{ Origin } \\
k-1776 & Name & Intended \\
k-2008 & Local & Kazakhstan & Grain crop \\
k-2759 & Local & Egypt & Feed crop \\
k-3283 & No name & Ethiopia & Feed crop \\
k-3654 & Local & Arkhangelsk Region & Feed crop \\
k-4376 & No name & China & Feed crop \\
k-4379 & G-11 & Kyrgyzstan & Grain crop \\
k-5054 & Local peas & Kyrgyzstan & Feed crop \\
k-5749 & White peas & China & Grain crop \\
k-7044 & Pinsky local & Belarus & Feed crop \\
k-7157 & Local No.26 & Libya & Grain crop \\
k-7307 & Local & Kenia & Grain crop \\
k-8858 & Kyyr & Estonia & Grain crop \\
& Flamingo & Kirov Region & Grain crop
\end{tabular}




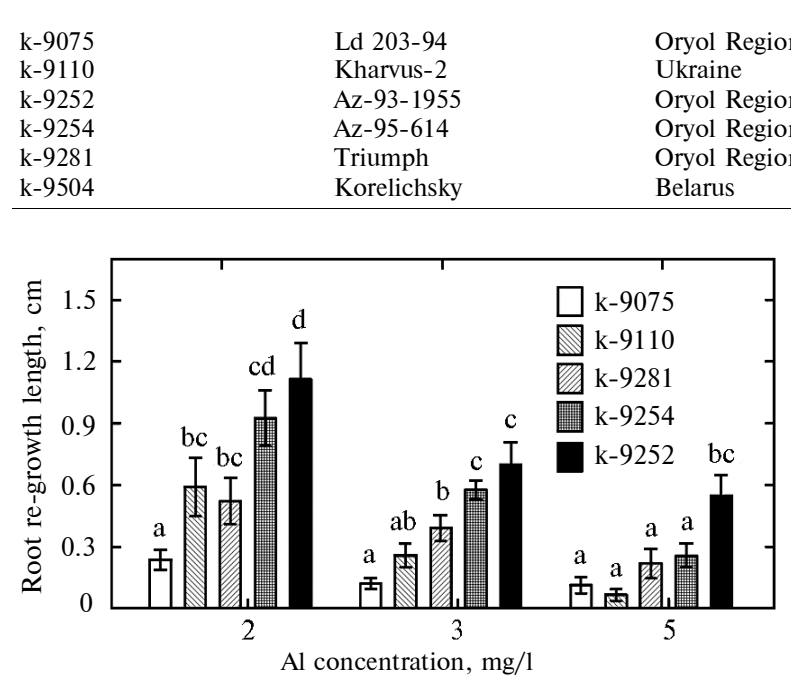

Fig. 1. Effect of various aluminum concentrations on root growth in garden pea (Pisum sativum L.) k-9075, k-9110, k-9281, k-9254, and k-9252 samples (VIR collection) based on the results of eriochrome cyanine $\mathbf{R}$ staining. Vertical segments mark standard errors. Different Latin characters indicate significant differences between the variants (Fisher LSD, P $\leq$ 0.05) ples were insignificant (probably due to the high degree of root growth inhibition by aluminum). However, the differences between the k-9252 and k-9254 samples became statistically significant at this concentration. Based on these results, a concentration of $3 \mathrm{mg} \mathrm{Al} / \mathrm{l}$ was chosen as a working (differentiating) concentration for further experiments, as the intersample differences were mostly clearly manifested at this concentration.

Root sprout staining with haematoxylin after the exposure to different concentrations of aluminum chloride in nutrient solution had no pronounced differences depending on pea samples. Ranking according to the damaged tissue staining intensity in some samples was difficult, despite the fact that the length of the root re-growth zone was generally greater in the samples with lower hematoxylin staining intensity (data not shown). This is probably due to the pea species characteristics, as in other plant species hematoxylin was successfully used to differentiate varieties by aluminum resistance by assessing the root staining intensity, and this figure was correlated with aluminum resistance growth rates $[4,19,20$, $22,36]$. Root treatment with eriochrome cyanine $\mathrm{R}$ revealed high variability of pea samples in staining intensity, and the root re-growth zone was visually distinguishable. The facts described confirmed the effectiveness of this dye for the study of intra-specific aluminum tolerability variation which had previously been demonstrated in cereals [2, 18, 30-32].

At the second study stage, we screened 14 pea samples treated with aluminum at a concentration of $3 \mathrm{mg} / \mathrm{l}$ and at root staining with eriochrome cyanine $\mathrm{R}$. The results showed high variability in root re-growth in peas following the toxic effects of aluminum, since sprout re-growing root length varied maximum 14-fold (samples k-2759 and k-7307) (Fig. 2). Samples k-3654 and k-3283 were also considered the least stable, and samples k-4376 and k-9504 were the most resistant ones. An aluminum tolerable pea varieties Flamingo (k-8858) created in the Kirov region in the area of acidic soils with mobile aluminum high 
content [24] used as the standard of aluminum tolerability was included in the studied samples. Our data showed this variety to have high aluminum tolerability but to be inferior to samples k-4376, k-9504, and k-7307 in the above characteristic. Since the number of studied pea samples is small, we cannot yet identify any relationship between the specimen characteristics (origin, intended use, phenotype) and the aluminum tolerability. But it is obvious that the samples of similar geographical origin may appear both aluminum tolerant and sensitive to aluminum, e.g. samples k-4376 and k-4379 from Kyrgyzstan.

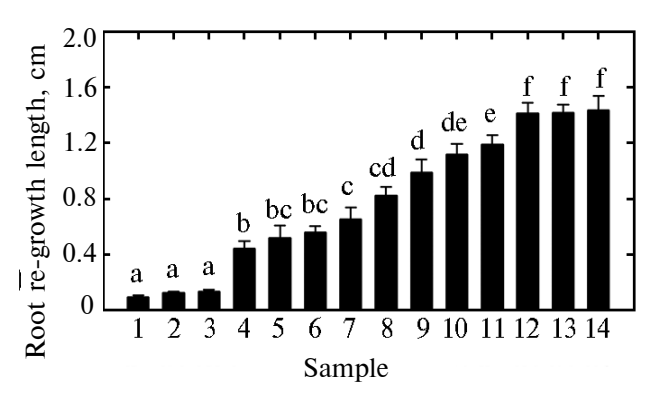

Fig. 2. Comparison of the effect of aluminum $(3 \mathrm{mg} / \mathrm{l})$ on root re-growth in the rapid assessment based on eriochrome cyanine $\mathbf{R}$ staining in garden pea (Pisum sativum L.) samples: $1-\mathrm{k}-2759,2-\mathrm{k}-3654,3-\mathrm{k}-3283$, $4-\mathrm{k}-5054,5-\mathrm{k}-4379,6-\mathrm{k}-5749,7-\mathrm{k}-$ $7157,8-\mathrm{k}-2008,9-\mathrm{k}-7044,10-\mathrm{k}-$ $8858,11-\mathrm{k}-1776,12-\mathrm{k}-4376,13-\mathrm{k}-$ 9504, 14 - k-7307 (VIR collection). Vertical segments mark standard errors. Different Latin characters indicate significant differences between the variants (Fisher LSD, P $\leq 0.05$ ).
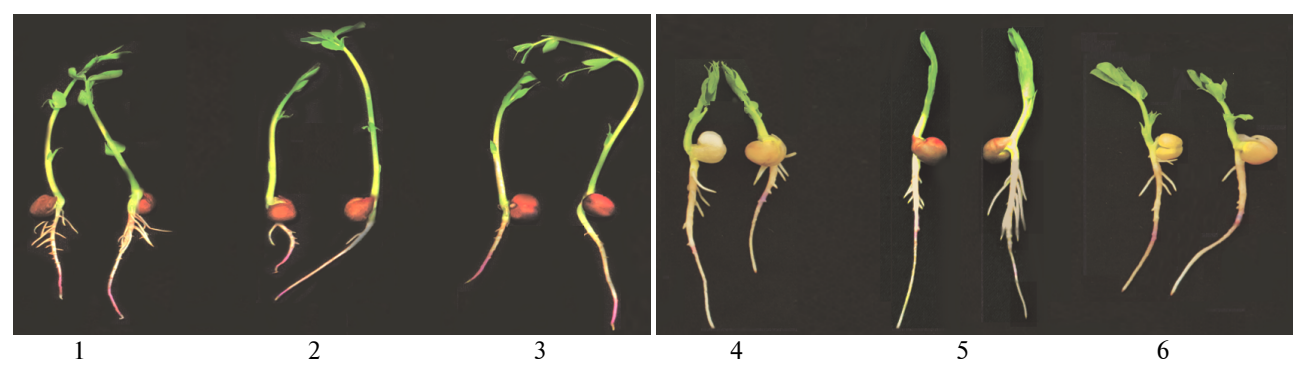

Fig. 3. Garden pea (Pisum sativum L.) seedlings in express test of Al-tolerance ( $3 \mathrm{mg} \mathrm{Al} / \mathrm{l})$ by staining roots with eriochrome cyanine R: $1-\mathrm{k}-2759,2-\mathrm{k}-3654,3-\mathrm{k}-3283$ (Al-sensitive); 4 - k-4376, 5 - k-9504, 6 - k-7307 (Al-tolerant) (VIR collection).

Significant intersample differences were observed in the intensity of root staining with eriochrome cyanine R. Samples with the minimum length of root re-growth (k-2759, k-3654, and k-3283) were characterized by intense purple color of the portion of the root treated with aluminum, and the samples with the maximum root re-growth length (k-4376, k-9504, and k-7307) had weak but detectable staining (Fig. 3). The intensity of eriochrome cyanine R staining characterizes the concentration of mobile (toxic) aluminum forms, and this figure is correlated with aluminum tolerability. If after aluminum treatment concentration of its active forms is low, root cell mitotic activity is restored, the root re-grows, and an achromatic re-growth zone appears next to the stained area [5]. The intensity of eriochrome cyanine $\mathrm{R}$ staining may be an additional indicator of the aluminum tolerance associated with the toxicant concentration in root tissue. Under the studied conditions, the root re-growth length characterizes the intensity of root tissue regeneration after the toxicant exposure. Screening using this indicator may be useful to identify the genotypes of the plants that can form an active root system when the seeds get into the soil with high aluminum concentration.

Thus, the proposed method is highly capable and reproducible which makes it possible to consider it a reliable way to assess pea potential aluminum tolerability at the earliest developing stages. However, under natural soil conditions, aluminum ion concentration is generally lower compared with the one of hydroponic cultures used for screening, and the root exposure to alu- 
minum is long and continuous. Therefore, we propose the developed method for a rapid assessment of aluminum tolerability to screen a wide range of genotypes followed by further study of contrasting forms with longer hydroponic growing (including the analysis of aluminum content in roots and sprouts) and under soil conditions.

\section{REFEREN CES}

1. Doklad o sostoyanii i ispol'zovanii zemel' sel'skokhozyaistvennogo naznacheniya [Report on the status and use of agricultural land]. Moscow, 2011 (http://agro.tmbreg.ru/files/zemDoklad_2011.pdf).

2. Aniol A., Gustafs on P. Chromosome location of genes controlling aluminum tolerance in wheat, rye and triticale. Can. J. Genet. Cytol., 1984, 26: 701-705 (doi: 10.1139/g84-111).

3. L a z of D.B., Holla nd M.J. Evaluation of the aluminium-induced root growth inhibition in isolation from low $\mathrm{pH}$ effects in Glycine max, Pisum sativum and Phaseolus vulgaris. Aust. $J$. Plant Physiol., 1999, 26: 147-157.

4. Akhter A., Wagat su ma T., K han M.S.H., Tawaray a K. Comparative studies on aluminum tolerance screening techniques for sorghum, soybean and maize in simple solution culture. Am. J. Plant Physiol., 2009, 4: 1-8 (doi: 10.3923/ajpp.2009.1.8).

5. K o s a r e va I.A. Trudy po prikladnoi botanike, genetike i selektsii, 2012, 170: 35-45.

6. Avd o n i n N.S. Izvestkovanie kislykh pochv [Liming acid soils]. Moscow, 1976.

7. Eswaran H., Reich P., B e in roth F. Global distribution of soils with acidity. In: Plant-soil interactions at low pH. A.C. Moniz et al. (eds.). Brazilian Soil Science Society, Campinas, 1997.

8. Sokolova T.A., Tolp e sht a I.I., Trofi mov S.Ya. Pochvennaya kislotnost'. Kislotnoosnovnaya bufernost' pochv. Soedineniya alyuminiya $v$ tverdoi faze pochvy $i$ v pochvennom rastvore [Soil acidity. Acid-base buffer capacity of soils. Aluminium compounds in the soil solid phase and solution]. Tula, 2012.

9. Kl i m a s h e v s k i i E.L. Geneticheskii aspekt mineral'nogo pitaniya rastenii [Genetic aspects of plant mineral nutrition]. Moscow, 1991.

10. Ry a n P.R., Dito m a so J.M., Ko ch i a n L.V. Aluminum toxicity in roots: an investigation of spatial sensitivity and the role of the root cap. J. Exp. Bot., 1993, 44: 437-446 (doi: $10.1093 / \mathrm{jxb} / 44.2 .437)$.

11. C i a m p r o v a M. Morphological and structural responses of plant roots to aluminium at organ, tissue, and cellular levels. Biologia Plantarum, 2002, 45: 161-171 (doi: 10.1023/A:1015159601881).

12. K o c h i a n L.V., H o e k e $\mathrm{ng}$ a O.A., P i n e r o s M.A. How do crop plants tolerate acid soils? Mechanisms of aluminum tolerance and phosphorous efficiency. Annu. Rev. Plant Biol., 2004, 55: 459-493 (doi: 10.1146/annurev.arplant.55.031903.141655).

13. Kobayashi Y., Yamamoto Y., Matsumoto H. Studies on the mechanism of aluminum tolerance in pea (Pisum sativum L.) using aluminum-tolerant cultivar «Alaska» and aluminum-sensitive cultivar «Hyogo». Soil Science and Plant Nutrition, 2004, 50(2): 197-204 (doi: 10.1080/00380768.2004.10408468).

14. Kikui S., S asaki T., Maekawa M., Miyao A., Hirochika H., Matsumoto H., Y a m a m o to Y. Physiological and genetic analyses of aluminium tolerance in rice, focusing on root growth during germination. Journal of Inorganic Biochemistry, 2005, 99: 1837-1844 (doi: 10.1016/j.jinorgbio.2005.06.031).

15. Schmohl N., Pilling J., Fisahn J., Horst W.J. Pectin methylesterase modulates aluminium sensitivity in Zea mays and Solanum tuberosum. Physiologia Plantarum, 2000, 109: 419-427 (doi: 10.1034/j.1399-3054.2000.100408.x).

16. Amenos M., Corrales I., Poschenrieder C., Illes P., B aluska F., B arcelo J. Different effects of aluminum on the actin cytoskeleton and brefeldin A-sensitive vesicle recycling in root apex cells of two maize varieties differing in root elongation rate and aluminum tolerance. Plant Cell Physiol., 2009, 50(3): 528-540 (doi: 10.1093/pcp/pcp013).

17. Choudhary A.K., Singh D. Screening of pigeonpea genotypes for nutrient uptake efficiency under aluminium toxicity. Physiology and Molecular Biology of Plants, 2011, 17(2): 145152 (doi: 10.1007/s12298-011-0057-7).

18. Kosareva I.A., Semenova E.V. Doklady Rossiiskoi akademii sel'skokhozyaistvennykh nauk, 2005, 5: 5-7.

19. Polle E.C., Konzak C.E., Kittrick J.A. Visual detection of aluminum tolerance levels of wheat by hematoxilin staining of seedlings roots. Crop Science, 1978, 18: 823-827 (doi: 10.2135/cropsci1978.0011183X001800050035x).

20. Cansado G.M.A., Loguercio L.L., Martins P.R. Parentoni S.N., Paiva E., Borem A., Lopes M.A. Hematoxylin staining as a phenotypic index for aluminum tolerance selection in tropical maize (Zea mays L.). Theor. Appl. Genet., 1999, 99: 747-754 (doi: 
$10.1007 / \mathrm{s} 001220051293)$.

21. Aniol A. Metody okreaślania tolerancyjności zbyż na toksyczne działanie jonyw glinu. Biul. Inst. Hodowli Aklim. Roslin., 1991, 243: 3-14.

22. Anas A., Yoshida T. Heritability and genetic correlation of Al-tolerance with several agronomic characters in sorghum assessed by hematoxylin staining. Plant Production Science, 2004, 7: 280-282 (doi: 10.1626/pps.7.280).

23. Singh D., Rai A.K., Panyang O. Hematoxilin staining as a potential screening technique for aluminum tolerance in pea. Curr. Sci., 2009, 96(8): 1029-1030.

24. Krop otov A.V. Kompleksnaya otsenka sortov ovsa i gorokha na kislotoustoichivost'. Kandidatskaya dissertatsiya [Comprehensive assessment of oat and pea varieties for acid tolerance. PhD Thesis]. Kirov, 2000.

25. Zanjanchi M.A., Noei H., Moghimi M. Rapid determination of aluminum by UV-vis diffuse reflectance spectroscopy with application of suitable adsorbents. Talanta, 2006, 70: 933939 (doi: $10.1016 /$ j.talanta.2006.05.056)

26. Tria J., Haddad P.R., Nesterenko P.N. Determination of aluminium using high performance chelation ion chromatography. Journal of Separation Science, 2008, 31(12): 22312238 (doi: 10.1002/jssc.200800046).

27. Sato T., Saito Y., Chikuma M., Saito Y., Nagai S. Fluorimetric determination of trace amounts of albumin in bronchoalveolar lavage fluid with eriochrome cyanine R. Biological and Pharmaceutical Bulletin, 2007, 30(7): 1187-1190.

28. Dapson R., Horobin R.W., Kiernan J. Hematoxylin shortages: their causes and duration, and other dyes that can replace hemalum in routine hematoxylin and eosin staining. Biotechnic and Histochemistry, 2010, 85(1): 55-63 (doi: 10.3109/10520290903048400).

29. Shokrollahi A., Ghaedi M., Niband M.S, Rajabi H.R. Selective and sensitive spectrophotometric method for determination of sub-micro-molar amounts of aluminium ion. Journal of Hazardous Materials, 2008, 151(2-3): 642-648 (doi: 10.1016/j.jhazmat.2007.06.037).

30. Niedziela G., Aniol A. Subcellular distribution of aluminium in wheat roots. Acta Biochimica Polonica, 1983, 30: 99-105.

31. Kosareva I.A. Semenova E.V. Tezisy Mezhdunarodnoi konferentsii «Problemy fiziologii rastenii Severa» [Proc. Int. Conf. «Physiology of Northern plants»]. Petrozavodsk, 2004.

32. Kosareva I.A., Davydova G.V., Se me nova E.V. Sel'skokhozyaistvennaya biologiya [Agricultural Biology], 1998, 5: 73-76.

33. Ko sa reva I.A., Oling a T.Zh. Izvestiya $S P b G A U$, 2007, 6: 47-49.

34. Zotikov V.I., Naumkina T.S., Sidore nko V.S. Vestnik OrelGAU, 2006, 1: 14-17.

35. Deb ely i G.A. Zernobobovye i krupyanye kul'tury, 2012, 2: 31-35.

36. Poschenrieder C., Gunsé B., Corrales I., Barcely J. A glance into aluminum toxicity and resistance in plants. Science of the Total Environment, 2008, 400(1-3): 356-368 (doi: 10.1016/j.scitotenv.2008.06.003).

37. An as A., Yoshida T. Screening of Al-tolerant sorghum by hematoxylin staining and growth response. Plant Production Science, 2000, 3: 246-253. 